the additional problem that this is a translation from Dutch, a language which I cannot read. So I owe it to Professor van Peursen to offer only a very cautious conclusion: I do not think that this English version of his book fulfils what I take to be its purpose.

"Clcar, comprehensive, scholarly", says the dust-cover, and the words are ironically well chosen. The author may be surprised to hear "scholarly", for scholarship was obviously not his intention at all. It is straight exposition, with no precise references to the texts, and only occasional mention of the titles of the works drawn on. There is no exegetical in-fighting, no delving into such questions as the changes in Leibniz's thinking through his life, though this is briefly sketched in the (likewise largely undocumented) first chapter. The book is, perhaps, learnedit is clear that van Peursen is closely acquainted with a tremendous amount of philosophical literature-but scholarly it is not.

This is not necessarily a defect. My complaints begin with the question of clarity, for much of the book is not clear at all. The book is described as ". . . the best kind of introduction for students" (again the dust-cover), but what a student is going to make of some of this, without already having a fair grasp of Leibniz's philosophy, is at best doubtful. Perhaps nothing - perhaps, worse, he will go away thinking he has understood when he has only grasped a verbal formula, like "it is a question of multiplicity being transposed into pure, interior concentration" (page 32). My concept of a monad is not advanced by this, even if we throw in the subsequent "elucidation". Page 83, to take just one other example, has some tricky terrain, such as the bit about the innumerable possible worlds which, even as mere potentialities, evince an urge to existence.

Much of the unclarity comes from a non-verbal source, however. The book is fairly comprehensive, but to achieve this in so few pages it has to survey its objects from a great distance. There is much insistence, not always convincing, on the up-to-dateness of Leibniz's thinking, as when his view that the monad contains all that is necessary fully to determine its future development is compared with the genetic code (pages 53-54). If you leave out enough details it is surprising what can be made to look alike ! There is hardly any discussion of the position attributed to Leibniz. Thus on page 93 (the most glaring case of several) where the topic is the freedom of the will, we are told that his answer to the question. "Was Caesar not bound to have crossed the Rubicon?" is that:

"Caesar was free and might even have been unab.e to cross the Rubicon; but in that case the logical subject 'Caesar' would have had different predicates and so would have been a different Caesar."

This is transparently hopeless. We did not ask whether there might not have been somebody else, very like Caesar, who need not have crossed the Rubicon; we asked whether Caesar had to cross it. But the book sails on as if all were in perfect order.

The panoptic chapter five is worth a read through. For an introduction to Leibniz, try the relevant chapters in Copleston's History of Philosophy.

E. J. Crato

\section{EPIC EXPLORATION}

\section{Lewis and Clark: Pioneering Naturalists}

By Paul Russell Cutright. Pp. xiii +506 . (University of Illinois Press: Urbana, Illinois and London, August 1969.) $\$ 12 \cdot 50 ; 119 s$.

THE great expedition of Captains Meriwether Lewis and William Clark from May 21, 1804, to September 21, 1806, whon they crossed the North American continent to reach the Pacific Ocean is well known to geographers and students of epic exploration. As a scientific expedition it has received scant attention. This was chiefly the result of the tragically early death of Lewis, who died in 1809 as governor of the newly acquired territory of Louisiana, before he could complete an account of the scientific results. By the time the journals of Clark and Lewis were published in 1814, they had been purged of nearly all their interest in the discjplines of zoology, botany, meteorology, and ethnology. Clark's aptitudo for cartography was masked, and many of his maps and the place names beswowed by the expedition never received proper recognition.

Dr Cutright's meticulous study of the expedition, and particularly the detailed quotations from the journals of the leaders (and several of their men), brings the participants to life in a remarkable way. Tho first written accounts, some being detailed descriptions, of many of the best known North American animals and plants date from the daily entries in Lewis's journals often written after a day of unremitting labour. The prairie rattlesnake, the eulachon or candle fish, the pronghorn, the coyote. the prairie dog, the mule deer and the grizzly bear are but a few of the animals they were the first to record. The tragedy of the expedition surely lies in the failure of Lewis, and perhaps Jefferson also, to publish accounts of these nondescript forms, many of which were not formally named up to thirty years later. It is fitting, however, that the beautiful cut-throat trout (Salmo clarki) and Lewis's woodpecker (Asyndesmus lewis) should commemorate the leaders.

The emphasis of this book is on the scientific work of the expedition. The observations on the animals, plants. and mincrals discovered, and the accounts of the Indian tribes, their languages and customs, wero of as great value as the straightforward trailblazing. Probably in the mind of the expedition's initiator and sponsor, Thomas Jefferson. they had a greater importance, for he had laid down the detailed guidelines for the observations to be made. Cutright's addition to the already voluminous literature of the Lewis and Clark expedition is of the greatest interest to naturalists and ethnologists. It is a scholarly work of which, one feels, Thomas Jefferson would have himself approved.

ALWYNe WHEELER

\section{HISTORY OF THE SOUL}

\section{Robert Whytt, the Soul and Medicine}

By R. K. French. Pp. 182. (The Wellcome Institute of the History of Medicine: London, July 1969.) $45 s$.

THE eighteenth century was decisive in determining the course of modern physiology, the problem of irritability and sensibility revived from Glisson, being the operative implement. It presented a three-fold aspect: site, mechanism and cause, the latter postulated by mechanistic. animistic and vitalistic views. This historical frame is used by Dr French to present a thorough biography, long overdue, of Robert Whytt.

Whytt's clinical accomplishments, romarkable but not very original, serve as a starting point of his physiological investigations. From the maze of involuntary motions and of sympathies between organs, assumingly controlled by the soul, Whytt disentangles the notion of reflex action by using Hale's brainless frog and relates it to circumscribed areas of the spinal cord. Theoretical considerations - no sympathies without fecling, no communication of feelings without nerves, wisdom or purpose-lead Whytt to adopt animism as an explanation of the nature of sensibility and irritability. His views conflicted with Haller's views and their controversy represents the most substantial part of the book. The author omits, for want of space, the contributions of other contemporary physi. ologists. An appraisal of the conduct of the experiments by the various protagonists, including Fontana, might have cleared some ground of the dispute. The argument lies on Haller's side who, cautiously, would not go beyond what 